\title{
Acquisition of bioluminescent trait by non-luminous organisms from luminous organisms through various origins
}

\author{
Chatragadda Ramesh ${ }^{1}$ (D) Manabu Bessho-Uehara ${ }^{2,3}$
}

Received: 7 June 2021 / Accepted: 20 October 2021 / Published online: 29 October 2021

(c) The Author(s), under exclusive licence to European Photochemistry Association, European Society for Photobiology 2021

\begin{abstract}
Bioluminescence is a natural light emitting phenomenon that occurs due to a chemical reaction between luciferin and luciferase. It is primarily an innate and inherited trait in most terrestrial luminous organisms. However, most luminous organisms produce light in the ocean by acquiring luminous symbionts, luciferin (substrate), and/or luciferase (enzyme) through various transmission pathways. For instance, coelenterazine, a well-known luciferin, is obtained by cnidarians, crustaceans, and deep-sea fish through multi-level dietary linkages from coelenterazine producers such as ctenophores, decapods, and copepods. In contrast, some non-luminous Vibrio bacteria became bioluminescent by obtaining lux genes from luminous Vibrio species by horizontal gene transfer. Various examples detailed in this review show how non-luminescent organisms became luminescent by acquiring symbionts, dietary luciferins and luciferases, and genes. This review highlights three modes (symbiosis, ingestion, and horizontal gene transfer) that allow organisms lacking genes for autonomous bioluminescent systems to obtain the ability to produce light. In addition to bioluminescence, this manuscript discusses the acquisition of other traits such as pigments, fluorescence, toxins, and others, to infer the potential processes of acquisition.
\end{abstract}

\section{Graphical abstract}

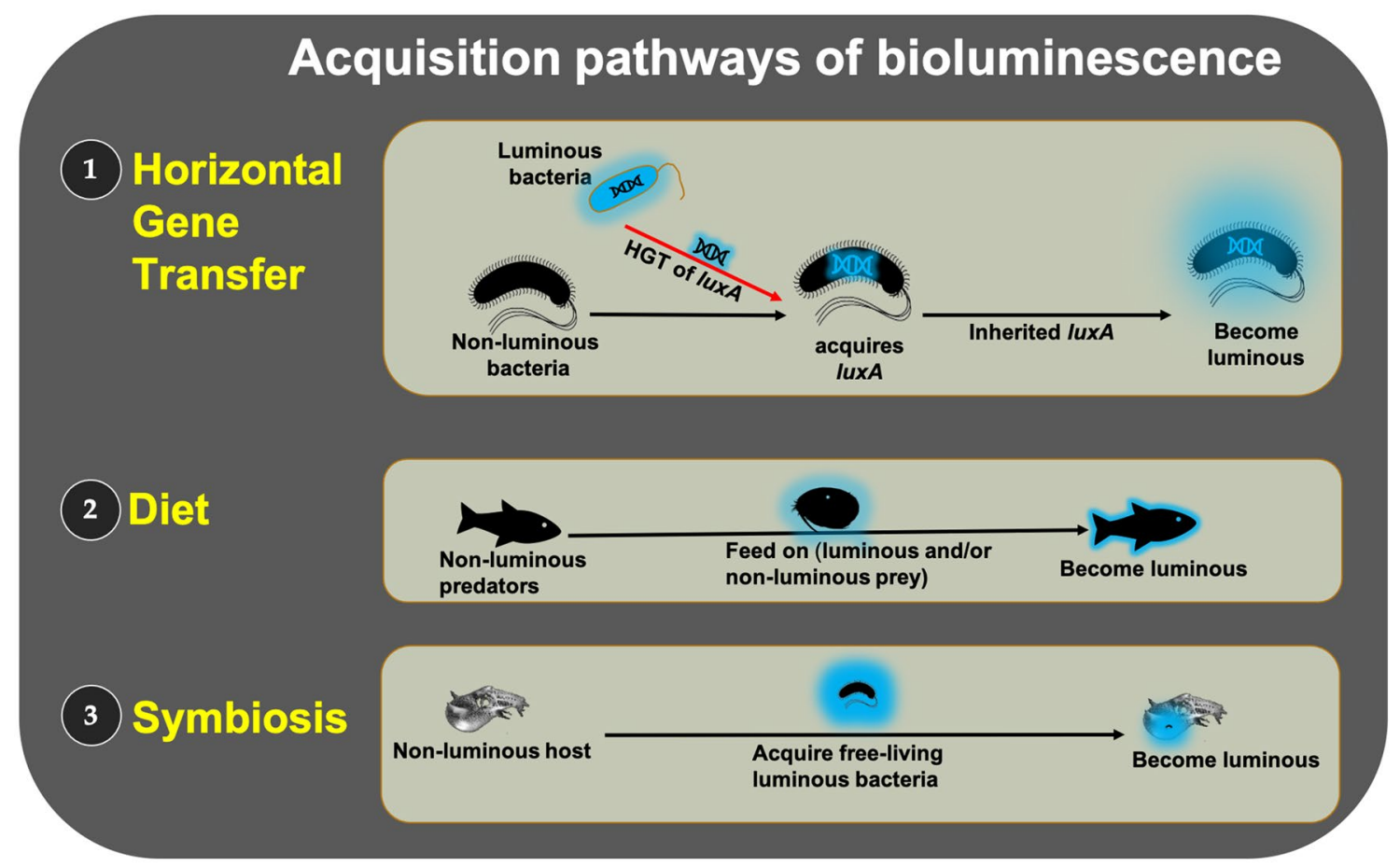

Extended author information available on the last page of the article 
Keywords Dietary luciferin $\cdot$ Acquired luminescence $\cdot$ Light organs $\cdot$ Deep-sea organisms $\cdot$ Coelenterazine

\section{Introduction}

Acquiring bioluminescent trait from other organisms is one of the fascinating topics in marine biology and ecology. Several prokaryotes and eukaryotes lacking innate bioluminescent traits are reported to obtain them from organisms bearing this trait through mechanisms such as prey ingestion or gene acquisition. The acquisition increases the ecological fitness of the organisms in many ways, such as for defense, predation, or communication $[1,2]$. These incidences are common in the ocean, although cases are not disseminated widely in the literature beyond the initial reports. We gathered literature describing various examples of organisms obtaining bioluminescent traits through three different modes to increase awareness of these natural events.

Bioluminescence is the natural phenomenon of light emission by living organisms. Individual luminous organisms primarily use an enzyme and a substrate (and co-factors in some cases) to generate light through an oxidation reaction. These organisms produce light upon stimulation or under certain conditions [3]. Various bioluminescent chemical reactions are known so far $[2,4,5]$. The mechanisms involved in obtaining the trait of bioluminescence are well studied [6-8], especially in fireflies by focusing on the mutation on an ancestral gene toward a luciferase $[9,10]$. Here, we detailed three alternative mechanisms that are involved in the acquisition of bioluminescence or other traits from closely or distantly related organisms:

HGT: in the first mechanism, horizontal gene transfer (HGT), a process where non-luminous organisms obtain mobile genes to become bioluminescent [11].

Ingestion: in the second case, several marine organisms in the ocean obtain either luciferin $[2,12]$ or both luciferin and luciferase [8] from their diet to produce light.

Symbiosis: in the third case, ingestion of or colonization by luminous bacteria results in the host macro-organism acquiring bioluminescence [13-19].

Bioluminescence is widespread in the ocean, present in about $76 \%$ of macroscopic organisms in water column [20] and $24-40 \%$ of benthic macrofaunal environments [21]. In many animals, bioluminescent courtship causes species diversification [22]. One mechanism of the acquisition of bioluminescent traits is accomplished by the dietary uptake of luciferins. However, the source organisms, biosynthesis, and dietary acquisition pathways of even the most common marine luciferin, coelenterazine, are not yet fully understood [2]. The transfer of dietary luciferins and genes within closely related or non-related organisms is rarely known in the ocean. Distribution patterns and acquisition pathways of intact forms of exogenous luciferins (e.g., euphausiids via dinoflagellate prey) in the food web are yet to be demonstrated [2]. The presence of vargulin, also known as cyprinid luciferin, in luminous fishes like Parapriacanthus and Apogon; and coelenterazine in various cnidarians, shrimps, squids, and fishes indicate the importance of studying the origin, biosynthesis, and dietary pathways of these luciferins [23]. In the case of cnidarians such as the crystal jelly, Aequorea must continuously obtain coelenterazine from dietary sources for light emission [12].

This review primarily deals with organisms emitting light upon acquiring luciferins, luciferases, and genes via dietary sources, horizontal gene transfer, and colonization by bacteria. This review aims to help researchers aware of gaps in our understanding of evolutionary processes, bioluminescence function, luciferin synthesis and transfer pathways, and the role of luciferins in food webs, even for non-luminous members.

\section{Horizontal gene transfer mediated luminescence}

During the course of evolution, organisms rarely integrate exogenous DNA into their genome resulting in an acquisition of a trait, such as antibiotic resistance, virulence, pigments, and bioluminescence: this mechanism is known as horizontal gene transfer (HGT). In the last two decades, there have been reports of acquired traits through HGT in prokaryotes [24] and metazoans [25] (Table 1; Table S1). For example, many pathogenic bacteria share their antibiotic genes and virulence genes within closely related or distantly related bacteria [26, 27]. Collimonas, a Gram-negative bacterium, produces blue pigments due to pigment gene acquisition via HGT, probably from Janthinobacterium lividum or Duganella sp. [28]. These acquired genes impart defensive function to these bacteria to fight against other microbes.

Likewise, luminescence trait acquisition via HGT has been reported in bacteria. The bacterial family Vibrionaceae comprises three major luminous bacterial genera such as Aliivibrio, Vibrio, and Photobacterium [29, 30]; while the genus Photorhabdus belongs to the Enterobacteriaceae [31], and Shewanella to Shewanellaceae family [32]. Luminescence in members of Aliivibrio, Vibrio, and Photobacterium is primarily due to vertical transmission (parent to progeny). In these bacteria, lux genes encode luciferases (luxA and $\operatorname{lux} B)$ and luciferin biosynthesis enzymes $(\operatorname{lu} x C, \operatorname{lu} x D$, and $l u x E$ ), altogether composing a lux operon. Many nonluminous bacterial strains of Vibrio and Photobacterium 
Table 1 Details of various organisms acquiring bioluminescence from luminous organisms through various modes

\begin{tabular}{|c|c|c|c|c|}
\hline Acquired gene/molecule/any & Receiving organism & Acquired from & Acquired via & References \\
\hline Coelenterazine & $\begin{array}{l}\text { Hydromedusae, Aequorea Victoria, and } \\
\text { Eutonina indicans }\end{array}$ & Coelenterazine containing diet & Diet & {$[12]$} \\
\hline Coelenterazine & Mysid, Gnathophausia ingens & Coelenterazine containing diet & Diet & [75] \\
\hline Coelenterazine & $\begin{array}{l}\text { Radiolarians, copepods, Cnidaria, } \\
\text { Ctenophora, Arthropoda, Mollusca, } \\
\text { and fishes }\end{array}$ & Coelenterazine containing diet & Diet & $\begin{array}{c}{[57-63} \\
145]\end{array}$ \\
\hline Coelenterazine & Ophiuroid, Amphiura filiformis & & Diet & [76] \\
\hline Dinoflagellate luciferin & Dinoflagellates & Probably photosynthetic organisms & Unknown & {$[55]$} \\
\hline Dinoflagellate luciferin & Krill & Dinoflagellates (Possibly) & Diet (Possibly) & {$[68]$} \\
\hline $\begin{array}{l}\text { Coelenterazine as squid } \\
\text { luciferin precursor }\end{array}$ & Cephalopods and octopods & Luminous organisms & Diet & [13] \\
\hline Cypridina luciferin & Midshipman fish, Porichthys notatus & Ostracod, Vargula hilgendorfii & Diet & {$[55,97]$} \\
\hline Cypridina luciferin & $\begin{array}{l}\text { Cardinalfish, Apogon, and sweepers, } \\
\text { Parapriacanthus, and Pempheris }\end{array}$ & Ostracod, Vargula hilgendorfii & Diet & $\begin{array}{l}{[57,100,} \\
101]\end{array}$ \\
\hline Luciferase & Sweeper, Parapriacanthus ransonneti & Ostracod, Cypridina noctiluca & Diet & [8] \\
\hline $\operatorname{lux} A$ & Vibrio species & Vibrio cholerae & HGT & {$[40]$} \\
\hline $\operatorname{lux} A$ & Non-luminous Vibrio species & Luminous Vibrio species & HGT & {$[11]$} \\
\hline lux-rib operon & Photobacterium leiognathi & Interspecies or Photobacterium strains & HGT & {$[42]$} \\
\hline lux-rib operon & P. mandapamensis & Interspecies or Photobacterium strains & HGT & [146] \\
\hline lux-rib operon & P. aquimaris & Photobacterium mandapamensis & HGT & {$[41]$} \\
\hline Aliivibrio fischeri & Juvenile Euprymna scolopes & Aliivibrio fischeri & Colonization & [116] \\
\hline Luminous bacteria & Zooplankton \& fish & Particulate organic matter & Feeding & [16] \\
\hline Photorhabdus spp. & Insect larvae & Nematodes of Heterorhabditidae family & Feeding & [142] \\
\hline Firefly & Rhacophoridae Frog & Firefly & Predation & [107] \\
\hline
\end{tabular}

Other phenotypic traits acquired by several organisms are detailed in the supplementary file (Table S1)

are known to acquire a lux operon for bioluminescence through HGT [11, 30] (Fig. 1). This type of luminescence is reported in non-luminous members related to luminous bacteria. These bacteria are known to display bright, dim, undetectable, or no-luminescence (dark mutants) [5, 33]. In the case of dark mutants carrying lux genes, which are often encountered on culture media, their failure to emit luminescence is due to insertion, deletion, and mutation in lux gene sequences [34-36]. HGT of lux genes from luminous members to non-luminous bacterial members of Vibrionaceae remains an unanswered question [11,30]. Without a regular cell division process, the mobile genetic elements were reported to transfer as individual genes or entire operons into recipients (other bacteria) [37-39]. These mobile genetic elements facilitate evolution in these microbes (Frost et al., 2005). The lux gene cluster has been suggested to be transferred from Vibrio cholerae to other luminous bacterial species [40]. Natural vertical inheritance of lux-rib operon (rib genes are involved in regulating riboflavin synthesis and luminescence) and horizontally acquired lux-rib operon from Photobacterium mandapamensis was also observed in luminescent strains of Photobacterium aquimaris [41]. In contrast, for certain Vibrio and Photobacterium strains, the HGT process (recruitment time of $l u x$ genes) under certain unknown environmental factors is not understood [11]. In the natural merodiploid state, strains of Photobacterium leiognathi carry single or multiple lux-rib operons obtained via HGT [42].

Non-luminous strains of Vibrio alginolyticus, Vibrio anguillarum, Vibrio owensii, and Photobacterium damselae, produce light upon acquiring lux genes [11]. The Photobacterium toruni also might obtain lux genes via HGT. Nonluminous bacterial strains of Kosakonia [43] and Kurthia sp. are thought to acquire lux genes through HGT to emit luminescence [44]. In all these cases, acquiring light-emitting genes resulted in non-luminous bacterial members producing luminescence in the natural environment. Acquisition of bioluminescent genes by non-luminous Vibrio species was postulated through bacteriophage infection, but no evidence has been found so far [45]. Leaky vertical transmission mode [46] has not been encountered so far in luminous bacteria (i.e., acquiring lux genes from both parent and environment). Members of Vibrionaceae are well known to display HGT of mobile genetic elements, which are involved in host range expansion, pathogenesis, and evolution [47]. Analyzing the flanking regions of the lux operon is a possible way to trace the origin of acquired genes in various bacterial phylogenies [40]. Once received, the trait of bioluminescence helps 

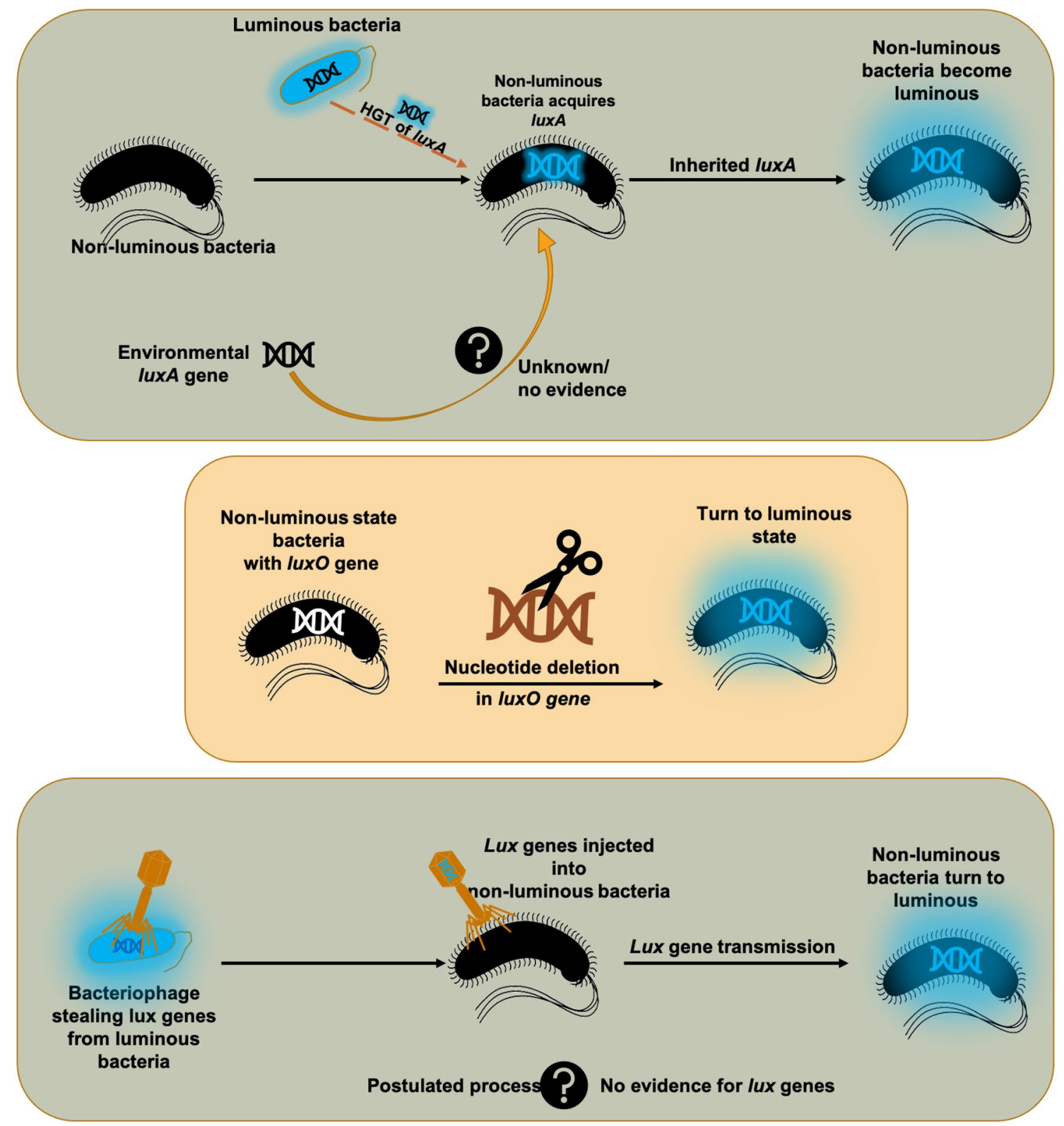

Fig. 1 Acquisition of bioluminescence trait through HGT, nucleotide deletion, and possibly through bacteriophage injection in non-luminous bacteria

defend the bacteria from predators so that the luminous population may be favored and propagated.

In contrast to luminous bacteria, metazoans are also presumed to acquired luciferase proteins or genes through HGT. For example, sea pansy Renilla luciferase (RLuc) shows an unexpected sequence similarity of $49-62 \%$ with haloalkane dehalogenases of bacteria and $40 \%$ similarity with a protein (possibly luciferase) from sea urchin Strongylocentrotus purpuratus [48]. The catalytic triad sequences of dehalogenases of bacteria and protein of $S$. purpuratus displayed a conserved homology with catalytic sites D120, E144, and H285 in RLuc sequence. For this reason, it is postulated that such incidents could occur via horizontal gene transfer [48]. However, no evidence has been reported so far to confirm that this haloalkane dehalogenases-like protein has luciferase activity in Renilla and $S$. purpuratus. These conserved catalytic residues are required for the activity of dehalogenases in bacteria but not in luciferase activity in sea urchin and Renilla [48]. Similarly, another study has also found such homologous sequences of luciferase of the ophiuroid Amphiura filiformis with Renilla luciferase [49]. Thus, haloalkanedehalogenase function was hypothesized to shift to luciferase activity in octocorals and brittle stars [49]. These 
studies suggest HGT as a possible process responsible for acquired traits in prokaryotes and metazoans.

\section{Dietary source based luminescence}

In this section, the various taxonomic groups of organisms showing dietary based luminescence are detailed. Some animals are also known to acquire poison characteristics by feeding on other animals and plants. For example, firefly Photuris females obtain lucibufagins from Photinus preys [50]; while firefly Ellychnia corrusca synthesizes or acquires lucibufagins [51]. Bright skin coloration and toxic lipophilic skin alkaloids in some poison dart frogs are probably obtained from the diet (e.g., various insects) [52, 53]. Similarly, monarch butterflies also acquire cardenolide toxic molecules from their milkweed host plants, Asclepias spp., to defend themselves from predators [54]. Those small organic compounds are broadly known to be passed through predation. In fact, luciferin molecules are acquired through the dietary pathway to predators.

\subsection{Dietary acquisition of organic molecules}

Food sources are key factors that regulate the morphological appearance, biochemical and metabolic processes, gene expression, and survival of nearly all heterotrophic life forms. As we humans need vitamins from dietary sources for our health, most organisms obtain essential chemical compounds for their biological functions from other organisms which can synthesize them. Many terrestrial (bacteria, fungi, beetle, etc.) and marine (bacteria, dinoflagellates, ctenophores, decapods, copepods, and ostracods) luminous organisms are known to produce their luciferin $[2,4,55]$. However, many more, even most marine luminous animals, rely their luciferin molecules on their diets [56-63]. The supplementation of luciferins from prey creates higher probabilities for predators to become bioluminescent. Luciferincontaining food becomes a preferred element of the diet, since dietary luciferin dependent luminous organisms need a steady supply to maintain luminescence.

Dinoflagellates are single-cell phytoplankton, which often cause bioluminescent blooms in the coastal waters associated with elevated temperature and nutrient availability. Their luminescence is usually triggered by mechanical disturbance via vacuolar proton channels [64]. The biosynthetic process of dinoflagellate luciferin has not been resolved [65], but the chemical structure of dinoflagellate luciferin highly resembles the chlorophyll molecule of photosynthetic organisms, indicating that dinoflagellate luciferin might be originated from the chlorophyll molecule (i.e., photosynthetic organisms) [55, 66, 67]. Euphausia (krill) luciferin possesses the same structural backbone as dinoflagellate luciferin [68-70]. It is believed that Euphausia obtains dinoflagellate luciferin and modifies it for euphausia's bioluminescence, but no evidence of luciferin uptake has been reported in Euphausia. Since dinoflagellate luciferin is structurally similar to krill luciferin and cross-reacts with the krill luminous system, studies suggested that krill luciferin may be obtained via diet $[2,71,72]$. Also, there is no evidence of the biosynthesis of krill's luciferin.

Coelenterazine, a luciferin originally discovered in coelenterates (former taxonomic classification including Cnidaria and Ctenophora), plays a significant role in many organisms' light emission, especially in the deep-sea [12]. Coelenterazine is also found in many non-luminous marine organisms (e.g., some fish, shrimps, and sponges) and was thought to be obtained via dietary pathways [73, 74]. An experimental study demonstrated the dietary requirement of coelenterazine in luminous Cnidarians. Hydromedusae, Aequorea victoria, and Eutonia indicans failed to emit light when fed a diet containing no coelenterazine [12]. However, feeding A. victoria and E. indicans with diets containing coelenterazine or supplements of coelenterazine reagent in water tanks containing hydromedusa specimens resulted in luminescence [12]. Since these cnidarians subsist mainly on gelatinous planktonic organisms [12], research needs to focus on these gelatinous organisms to understand the actual source of coelenterazine and its transfer within the food web. In other experiments, the bioluminescent lophogastrid shrimp Gnathophausia ingens could produce luminescent secretions when tested with various luminous food types, including Triphoturus, Cyclothone, Atolla, Sergestes, and Gaussia, which contains coelenterazine. However, the shrimp failed to luminesce when fed on euphausiid or Porichthys, which do not contain coelenterazine but different luciferins [75]. Digestive tracts of various shrimps, including G. ingens possessed exogenous dietary luciferin responsible for luminescence [75]. The luminescence capabilities of brittle star, Amphiura filiformis (Ophiuroidea) was observed by feeding A. filiformis with a coelenterazine-free diet and coelenterazine supplemented food. Experimental results showed depleted luminescence with coelenterazine-free diet and recovered luminescence when fed with coelenterazine supplemented food, suggesting that A. filiformis obtain a dietary coelenterazine to maintain luminescence capability [76]. Considerably, luminescence in fishes is widespread [77], and most of them are known to obtain dietary luciferin to produce light $[78,79]$. For example, lantern sharks in the genus Etmopterus use coelenterazine for light emission. Those sharks probably obtain coelenterazine from fishes, crustaceans, and copepods based on their stomach contents [80]. These incidences indicate that some bioluminescent animals lack the capability of luciferin biosynthesis but can produce light upon obtaining luciferins through diet. Only a few animals are known to possess the capability of 
coelenterazine biosynthesis, such as copepod, shrimp, and ctenophore [6, 7, 81-84]. These animals must therefore serve as a primary dietary source for coelenterazine dependent luminous organisms. Noteworthy, some coelenterazine users such as Vampyroteuthis, Oikopleudae, and Amphiura feed on detritus (marine snow or mud) materials in which coelenterazine is not protected in cells from oxidation. Because free coelenterazine molecules are highly unstable, coelenterazine in the detritus is likely to be autoxidized and to form non-active reactant, coelenteramide, or coelenteramine. It is unknown how those animals can obtain active coelenterazine from such diets.

The stable forms of coelenterazine such as enol-sulfate and dehydrocoelenterazine were detected in the tissues of few myctophid species, which are hypothesized to be derived from the diet [74]. Detection of coelenterazine in the gonads of few myctophid species $[74,85]$ and presence of ventral photophores in the late embryonic stage of the lantern shark Etmopterus spinax $[80,86]$, suggests the maternal transfer of bioluminescent substrates to offspring. Several deep-sea non-luminous cephalopods and octopods contained luminous substrates in their tissues and organs, apparently due to ingestion and accumulation of a coelenterazine and a de-hydrocoelenterazine [13]. However, the possibility that the cephalopods can biosynthesize those luciferins is not addressed. Coelenterazine was extracted from an enoploteuthid squid Watasenia scintillans, a myctophid fish, an oplophorid shrimp, and cnidarians, indicating that coelenterazine may be of dietary origin in the midwaters [13].

Despite the well-known dietary pathway of coelenterazine acquisition among different organisms, the actual biosynthetic mechanism remains unknown, although the total chemical synthesis of coelenterazine has been reported [87-94]. Although there could be alternative synthetic mechanisms in various luminous or non-luminous organisms in the ocean [57]. Coelenterazine was detected in the eggs of Argyropelecus hemigymnus, supporting the hypothesis of a maternal transfer of luminous capabilities [60]. In another observation, increasing coelenterazine concentrations were detected during the development of eggs to adults for the decapod crustaceans, Systellaspis debilis, Oplophorus spinosus, and Acanthephyra purpurea [81, 82]. However, there is no evidence for the specific biosynthesis mechanism of coelenterazine throughout development in these species.

The biosynthesis of coelenterazine luciferin using two molecules of L-tyrosine and one molecule of L-phenylalanine has been documented for two deep-sea copepod Metridia pacifica [83], and M. lucens [95]. Earlier studies postulated a mechanism in which mutation in the peptide serine-tyrosine-glycine (SYG) to form the tripeptide phenylalanine-tyrosine-tyrosine (FYY) could be involved in coelenterazine biosynthesis in cnidarians and decapod crustaceans [81]. The comparative transcriptomic analysis found an isopenicillin-N-synthase with FYY sequence on the C-terminus in luminous ctenophores, but the homologs in non-luminous ctenophores lacked FYY sequence [96]. Luminous ctenophores Mnemiopsis leidyi and Bolinopsis infundibulum were shown to be capable of coelenterazine biosynthesis, but the non-luminous ctenophore Hormiphora californiensis lacked the capability [7]. However, the involvement of the FYY gene in coelenterazine biosynthesis lacks experimental evidence [7]. Thus, further research is needed to identify and prove the chemical mechanism for tripeptide-based coelenterazine synthesis in coelenterazine dependent decapods, ctenophores, and other organisms [81]. Investigations on transcriptome data of luminous and nonluminous organisms and gene-knockout experiments would unveil the coelenterazine biosynthetic pathways in the near future [96].

Vargulin, a luciferin originally found from the luminous ostracod Vargula hilgendorfii (previously Cypridina hilgendorfii), is also acquired by predators for bioluminescence. The midshipman fish Porichthys notatus was observed to have dim, undetectable, or no luminescence depending on collection location [97]. P. notatus gained luminescence capability upon being given pure vargulin or after feeding on luminous ostracod Vargula tsujii and V. hilgendorfii [97] or gelatin capsules containing dried Vargula or intraperitoneal injection of luminous Porichthys tissue extracts [98]. The absence of dietary luciferin in food [99] or a diet of other luminous organisms did not result in any luminescence in $P$. notatus [97]. Similar cases have been observed for the cardinalfish Jaydia ellioti (=Apogon ellioti) [100] and golden sweepers Parapriacanthus ransonneti, whose luminescence was produced upon feeding on exogenous luciferin diet from a sympatric ostracod Vargula hilgendorfii [57, 100, 101].

The ability to synthesize vargulin has been demonstrated in V. hilgendorfii [102]. Three amino acids L-arginine, L-isoleucine, and L-tryptophan are the required substrates [103]. Similar to coelenterazine biosynthesis, cyclization of the tripeptide is thought to be involved, but the detailed pathway remains unknown $[2,96]$. There is little detail about the mechanism of synthesis of coelenterazine in decapod crustaceans [81], deep-sea copepod Metridia pacifica [83] and ctenophores [7]. A recent study postulated that pyrosomes might obtain coelenterazine-like luciferin from dietary sources [104], although the actual source in its diet of phytoplankton is unclear. Thus, further research is required on the dietary origin of coelenterazine and vargulin luciferin in crustaceans and other organisms to identify their biosynthetic pathways and substrate flow through the food web. In most marine organisms, the acquired bioluminescence is thought to be used in defensive functions. 


\subsection{Dietary acquisition of protein or larger functional module}

Aside from small organic compounds, larger molecules and cellular components such as proteins and cell organelles are generally vulnerable to digestion. There have been a few reports of the exceptions, for example, sacoglossan sea slugs can sequester chloroplasts from their algal food and maintain their photosynthetic function. The maintenance of the acquired chloroplast (kleptoplast) is independent of HGT, but some involvement of kleptoproteins from the algae has been postulated [105]. Sequestered cnidocytes (kleptocnidae) are known from the comb jelly Haeckelia (Ctenophora), nudibranchs (Mollusc), flatworms (Platyhelminthes), and Acoelomorpha [106]. In addition to small compounds, these cell organelles are rarely but certainly integrated into the predators, but protein uptake has not been known until recent.

The golden sweeper, Parapriacanthus ransonneti, obtains and uses not only luciferin but also luciferase by consuming the ostracod, Cypridina noctiluca [8]. This study was the first report of sequestration of a protein with its function intact, and it was termed a kleptoprotein system. P. ransonneti is also capable of sequester luciferase of $V$. hilgendorfii, showing $84 \%$ amino acid identity to the luciferase of C. noctiluca, if fed in the laboratory condition. The fish uses kleptoprotein bioluminescence for counter illumination, so it needs to supplement vargulin and cypridinid luciferase constantly. As many marine animals utilize coelenterazine, it is possible that some of them also use a kleptoprotein for their bioluminescence. The molecular mechanisms involved in protein uptake, as well as kleptoplastids and kleptocnidids, from diets are not understood.

\subsection{Dietary acquisition of individuals}

A few observations have recorded the occurrence of temporary luminescence from non-luminous organisms due to feeding on luminous organisms. Certain amphibians, lizards, spiders, ants, birds, and mammals are reported to be the predators of fireflies [107]. These predators are attracted to firefly light, prey on them, as a result, flashes of temporary luminescence are observed in predators with soft-bodied tissues. Light ceases as the firefly digests in the stomach. We hypothesize that regular or occasional predation on bioluminescent organisms by predators might facilitate the potential for evolutionary processes to develop a prototype luminous system (having either luciferin or luciferase in their body) or kleptoprotein system.

\section{Symbiosis-mediated luminescence}

Visual appearance is usually innate character well known as cases of pigment. However, the literature suggests that the dissemination of pigment traits may also be imparted through symbiotic organisms. Dolastatin, an antitumor yellow molecule and other molecules isolated from sea hares and other molluscs, is originally biosynthesized by their symbiotic cyanobacteria [108, 109]. Pigment molecules produced by different seagrasses, sponges, corals, molluscs, and tunicates are produced by their epibiotic bacteria [110]. Tambjamine pigments characterized from bryozoans, Bugula dentata and Sessibugula translucens, nudibranchs, and ascidian, Atapozoa sp. are produced by endobiotic or epibiotic Streptomyces sp., Pseudoalteromonas tunicata, and Serratia marcescens [111-114].

Similarly, the association between luminous bacteria and host organisms results in symbiosis-mediated luminescence (Fig. 3). Host organisms lack genetic sources to produce light; therefore, without the luminous symbionts, the host organisms remain non-luminous. Most vertebrates and molluscs, which display luminescence with the aid of symbiotic luminous Vibrio and Photobacterium species, have specific organs to harbor luminous bacteria, so-called "light organs" [115]. Symbiotic bioluminescence in the Hawaiian bobtail squid Euprymna scolopes has been well studied. E. scolopes harbors luminous bacteria in its light organ located below the eyes and ejects Aliivibrio fischeri as a cloud of light into surrounding waters to escape from predators. The expelled free-swimming luminous bacteria colonize on a new host (e.g., the symbiosis between Alivivibrio fischeri and Euprymna scolopes) [116]. The leftover luminous bacterial cells present in the light organs will again proliferate to requisite cell density by nightfall. A. fischeri in the light organ do not possess flagella, but once the bacteria are ejected into the ocean, they transform to have flagella and freely move through the water [34, 117]. Those bacteria again colonize on the juvenile squids as a cyclical process of symbiosis via (1) a series of reciprocal chemical communication between host and symbiont [116], (2) flagellum based motility towards the light organ [118] and (3) their attachment to mucus secreted by the ciliated epithelia of the squid light organ [119].

The process of how free-living bacteria initiate colonization on the host is partially understood in the shallow waters (Fig. 3a-c). Luminous bacteria are ubiquitous in the ocean and can be seen in various forms such as saprophytic, enteric (surviving or growing in gut tracts of animals), and light organ symbionts [120]. Depending on the host, luminous symbionts use surface-binding pilin proteins and secretion proteins for colonizing the new host [121]. 
A study reported the colonization of A. fischeri SR5 on its natural host squid, Sepiola robusta, and heterologous squid host, E. scolopes [122]. In contrast, the monocentrid fish luminous symbiont, A. fischeri MJ11 failed to colonize heterologous host $E$. scolopes, indicating the strain-host specific colonization [122, 123] (Fig. 3a). A recent study identified the diketopiperazine molecule required for a symbiotic relationship between the microbial symbiont $A$. fischeri and its host Euprymna scolopes [124]. But the same bacterial species failed to colonize other potential hosts, like monocentrid fish (Fig. 3b). This indicates that research is needed on symbiont-specific colonization of luminous bacteria with different fishes. Some marine fishes produce light with the aid of luminous bacteria. These fish culture luminous bacteria in their light organs and release them into seawater when they proliferate to the excessive densities. And, the released bacteria recolonize new generations of the same host [128], or may colonize other luminous and non-luminous organisms $[120,125,129]$. Anomalopidae, monocentrid fish, and angler fish are known to release luminous bacteria from their light organs and intestine excretions into the external environment and maintain the bacterial count in their light organs $[125,126]$. Cardinal fish Siphamia releases luminous feces composed of luminous bacteria cultured in the light organ, connected to its digestive tract [127]. Some zooplankton and fishes are also attracted to bacterial bioluminescence primarily associated with particulate organic matter (Fig. 2b). The bacterial bioluminescence in the gut of those planktons and small fish can be seen through the transparent bodies, which become vulnerable to nocturnal fish or coprophagic organisms by attracting them to light $[16,130]$. These bacteria survive during digestion, grow in the nutrient rich intestinal tracts [130], and are released back into the environment through the predators' feces, which results in the propagation of the luminous bacteria [16]. The dispersion and propagation of luminous bacteria through the attraction of light associated with fecal pellets and sediment particles is also supported by a previous study on copepods [17]. Fresh fecal pellets of copepods were found with a high count of luminous bacteria, which are known to be involved in the decomposition of fresh fecal pellets during egestion [17]. Subsequently, these bacteria are again released back into the seawater through feces. However, it is not yet known whether such association could be transient or permanent [129], indicating a promising area for future research.

In the deep-sea environment, the cosmopolitan free-living luminous bacteria, Photobacterium kishitanii, is associated with skins and light organs of diverse deep-dwelling fishes [131]. Many deep-sea animals display host-specific colonization by luminous bacteria [120]. The genomes of deepsea angler fish luminous symbionts, Candidatus Enterovibrio escacola, and Candidatus Enterovibrio luxaltus were observed to be reduced to $50 \%$ from actual genome size after colonization, compared to free-living luminous symbionts [132]. Similarly, such incidents of reduced genome contents after colonization were reported in flashlight fish symbionts. The genome content of pseudo-vertically transmitted flashlight fish luminous symbionts such as Candidatus Photodesmus blepharus, and Candidatus Photodesmus katoptron were reduced to moderate or extreme levels [121, $128,133]$. The same species of symbionts were observed to colonize the light organs of a majority of the deep-sea angler fish, except Cryptopsaras couesii that colonized Candidatus Enterovibrio luxaltus [134]. Adult stage angler fish acquire free-living luminous bacteria, while these symbionts are absent in larval specimens [135]. Unlike the known colonization mechanism of luminous bacteria with bobtail squid [116], the actual mechanism of colonization and transmission of luminous bacteria with anglerfish is not yet understood. Based on 16S rDNA, luciferase operon, and other housekeeping genes analysis, HGT is proposed as a possible mechanism involved in the colonization of enterovibrio bioluminescent symbionts from the environment to the light organs of anglerfish [134, 135]. However, based on the luminous bacterial genomes, recent studies suggest that motility and chemotaxis are perhaps important for luminous bacteria to colonize angler fish [121, 133, 134].

Rare phenomena such as the formation of milky sea [136, 137] and deep-sea bioluminescent blooms [138] are largescale examples of quorum-sensing mediated luminescence. Milky sea and deep-sea bioluminescent blooms are the two luminescent phenomena observed in surface water and deep-sea waters, correspondingly. In both events, luminous bacteria are involved. In the former event, luminescence is triggered by autoinducer molecules, whereas in the latter event, nutrients and other chemical elements are thought to be involved. A satellite captured an area of about 15,400 $\mathrm{km}$ [2] luminescing, known as milky sea, in the Arabian Sea, which has been linked to luminous bacteria Vibrio harveyi associated with microalga Phaeocystis blooms in the surface waters (Fig. 3c). This bacteria releases enormous quantities of quorum sensing autoinducer molecules with Phaeocystis bloom to form milky sea [136]. The microalga Phaeocystis is not luminescent, but the enormous load of $V$. harveyi on this alga generates intense luminescence. Milky seas are sometimes exceeding 100,000 km [2] in size and continues for days to weeks [137]. It is unknown whether or not fish and crustaceans feed on milky sea. In contrast, deepsea bioluminescence blooms were suggested to occur due to luminous bacterial densities triggered by nutrient availability through open-sea convection [138]. The actual factors triggering the development of these two phenomena have not yet been investigated experimentally in situ only surmised from in vitro comparisons. The ecological roles of milky sea and bioluminescent bloom, how this enormous luminescence benefits on the luminous bacteria, remain unknown. 


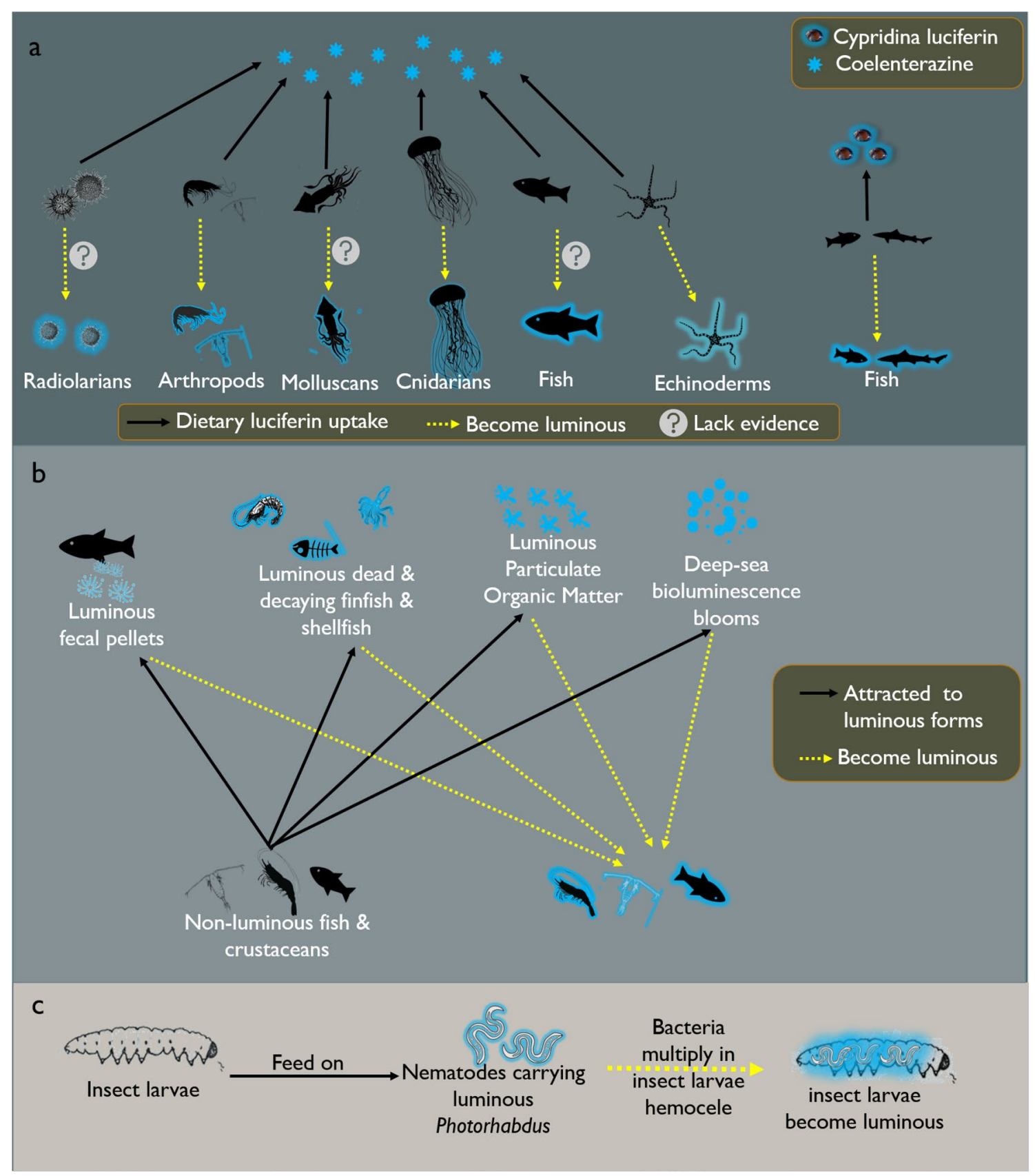

Fig. 2 Acquisition of luminescence through dietary source, ingestion, colonization, and chemical triggering in different organisms. a Dietary luciferin uptake by various groups of organisms. b Some nonluminous crustaceans and fish are attracted to various luminous forms (colonized by luminous bacteria and to less extent dinoflagellates) such as fecal pellets, dead and decaying finfish, and shellfish, partic-

In contrast to symbiosis, saprophytic luminous bacteria are often reported to colonize and spread on dead organisms. A dead specimen of seabream kept in a refrigerator produced light from its surface skin after a couple of days due to the proliferation of epibiotic marine luminous bacteria. In this case, it is not due to symbiotic bacteria in it but ulate organic matter, and deep-sea bioluminescence blooms feed on them and display a temporary luminescence. c Ingestion of luminous Photorhabdus by insect larvae. Silhouette icons were obtained from PhyloPic.org and iconfinder.com. Other images (copepods and radiolarians) are courtesy of anonymous artists

saprophytic luminous bacterial proliferation. The brackish water amphipod, Pontogammarus maeoticus, was reported to emit a steady green light from its whole body, postulated to be of bioluminescent bacterial origin [139]. However, luminescence in these amphipods is not because of symbiotic colonization but thought to be due to the aggregation 


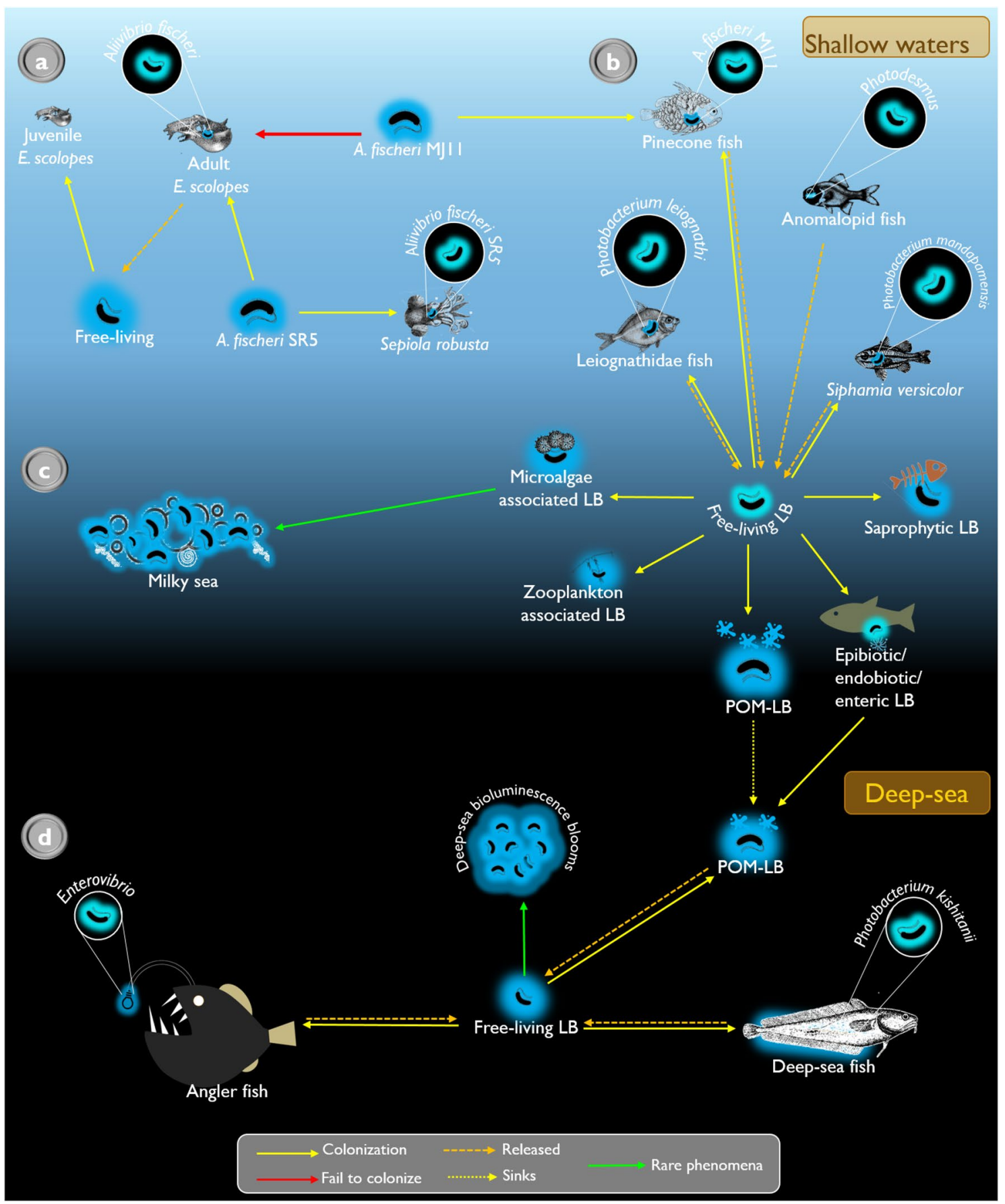

Fig. 3 Colonization of free-living luminous symbionts by different host organisms. a Luminous bacteria (LB)-Squid colonization; b LBfish colonization; c LB-non-luminous organisms or LB-organic mat-

and proliferation of pathogenic luminous bacteria. It is yet to be confirmed whether this incident is occasional or recurrent and whether these amphipods obtained luminous bacteria through diet or natural infection. A previous study suggested that the fluids of crustaceans are often infected with luminous bacteria, which might be possibly pathogens or merely opportunists [129]. Marine saprophytic luminous bacteria ters colonization in shallow water; d LB-Deep-sea fish colonization. POM-LB, particulate organic matter associated LB

were reported to cause luminescence in different fish, meat, and eggs [30]. Similarly, many terrestrial samples such as a variety of insects, eggs of chicken and lizards, mutton, decaying bodies of marine and terrestrial organisms, human wounds, and corpses were reported to luminesce, which is attributed to the colonization of terrestrial luminous bacterial species belonging to the genus Photorhabdus [30, 140]. 
The terrestrial bioluminescent Photorhabdus bacterial species is reported to be a human pathogen and a symbiont of the nematode family Heterorhabditidae [141]. When insect larvae feed on nematodes carrying Photorhab$d u s$, nematodes release these luminous bacteria into the insect larva hemocoel, where luminous bacteria replicate, produce toxins, and kill the insect larva for nutrients for themselves and the nematodes. At this stage, the dead specimens of insect larvae begin to glow because of light production from proliferating luminous bacteria in the hemocoel [141, 142] (Fig. 2). Luminescence emitted from the dead insect larvae would possibly help newly reproduced nematode larvae attract and infect new insect larvae [143, 144]. The ecological role of this luminescence in the dead insect body is not understood.

\section{Conclusion}

As detailed above, there have been few studies showing that some non-luminous organisms may become luminescent via various dietary, HGT, or symbiotic pathways. Since many of these pathways are not well understood, research on these aspects would provide new insights on convergent evolutionary pathways [85]. Analyzing the luminescence activity of various animals' gut contents will help determine the chemistry and genetics behind the dietary flow of luciferins and luciferases through the food web. Studying the milky sea and deep-sea bioluminescent bloom events using satellites and deep-sea bathyphotometers, respectively, would provide a deeper understanding of the occurrence and impact of these phenomena. The mechanisms and ecological functions of acquired genes and foods in non-luminous organisms also need further investigation. The ability to luminesce by non-luminous organisms is linked with evolutionary mechanisms. Thus, studies are required on two aspects: (1) how light organs (or related tissues) of the organisms are specialized to sense and integrate foreign molecules, genes, or microbes from donor organisms; (2) how the molecules, genes, or bacteria avoid host immune system or digestive system before integrating into the host organism.

Supplementary Information The online version contains supplementary material available at https://doi.org/10.1007/s43630-021-00124-9.

Acknowledgements The authors thank Prof. Dr. Steven Haddock, Senior Scientist, Monterey Bay Aquarium Research Institute, for his valuable suggestions, corrections, and editing to improve this manuscript. We acknowledge the anonymous reviewers for their helpful comments to organize this review perfectly. CR thank the Director, NIO, for institutional support and funding under the project OLP2005. CR also thanks to the Department of Science and Technology for the INSPIRE fellowship DST/IF120230/2012/280 and Science and
Engineering Research Board for the National Postdoctoral Fellowship SERB/PDF/2016/000354. This is CSIR-NIO's contribution reference number 6825 .

\section{Declarations}

Conflict of interest The authors do not have any conflict of interest to declare.

\section{References}

1. Kahlke, T., \& Umbers, K. D. L. (2016). Bioluminescence. Current Biology, 26, R307-R318.

2. Haddock, S. H. D., Moline, M. A., \& Case, J. F. (2010). Bioluminescence in the sea. Annual Review of Marine Science, 2, 443-493.

3. Ramesh, C. H., \& Meyer-Rochow, V. B. (2021). Bioluminescence in aquatic and terrestrial organisms elicited through various kinds of stimulation. Aquatic Ecology, 2021, 1-28.

4. Kaskova, Z. M., Tsarkova, A. S., \& Yampolsky, I. V. (2016). 1001 lights: Luciferins, luciferases, their mechanisms of action and applications in chemical analysis, biology and medicine. Chemical Society Reviews, 45, 6048-6077.

5. Ramesh, C. H. (2020). Terrestrial and marine bioluminescent organisms from the Indian subcontinent: A review. Environmental Monitoring and Assessment, 192, 747.

6. Bessho-Uehara, M., Francis, W. R., \& Haddock, S. H. D. (2020). Biochemical characterization of diverse deep-sea anthozoan bioluminescence systems. Marine Biology, 167, 114.

7. Bessho-Uehara, M., Huang, W., Patry, W. L., Browne, W. E., Weng, J. K., \& Haddock, S. H. D. (2020). Evidence for de novo biosynthesis of the luminous substrate coelenterazine in ctenophores. iScience, 23, 101859.

8. Bessho-Uehara, M., Yamamoto, N., Shigenobu, S., Mori, H., Kuwata, K., \& Oba, Y. (2020). Kleptoprotein bioluminescence: Parapriacanthus fish obtain luciferase from ostracod prey. Science Advances, 6, 4942.

9. Fallon, T. R., Lower, S. E., Chang, C. H., Bessho-Uehara, M., Martin, G. J., Bewick, A. J., Behringer, M., Debat, H. J., Wong, S., Day, J. C., Suvorov, A., Silva, C. J., Stanger-Hall, K. F., Hall, D. W., Schmitz, R. J., Nelson, D. R., Lewis, S. M., Shigenobu, S., Bybee, S. M., ... Weng, J. K. (2018). Firefly genomes illuminate parallel origins of bioluminescence in beetles. eLife, 7, e36495.

10. Kotlobay, A. A., Sarkisyan, K. S., Mokrushina, Y. A., MarcetHouben, M., Serebrovskaya, E. O., Markina, N. M., Somermeyer, L. G., Gorokhovatsky, A. Y., Vvedensky, A., Purtov, K. V., Petushkov, V. N., Rodionova, N. S., Chepurnyh, T. V., Fakhranurova, L. I., Guglya, E. B., Ziganshin, R., Tsarkova, A. S., Kaskova, Z. M., Shender, V., ... Yampolsky, I. V. (2018). Genetically encodable bioluminescent system from fungi. Proceedings of the National Academy of Sciences of the United States of America, $115,12728-12732$.

11. Urbanczyk, H., Ast, J. C., Kaeding, A. J., Oliver, J. D., \& Dunlap, P. V. (2008). Phylogenetic analysis of the incidence of lux gene horizontal transfer in Vibrionaceae. Journal of Bacteriology, 190, 3494-3504.

12. Haddock, S. H. D., Rivers, T. J., \& Robison, B. H. (2001). Can coelenterates make coelenterazine? Dietary requirement for luciferin in cnidarian bioluminescence. PNAS, 98, 11151.

13. Young, R. E., Roper, C. F. E., Mangold, K., Leisman, G., \& Hochberg, F. G., Jr. (1979). Luminescence from non-bioluminescent tissues in oceanic cephalopods. Marine Biology, 53, 69-77. 
14. Herren, C. M., Alldredge, A. L., \& Case, J. F. (2004). Coastal bioluminescent marine snow: Fine structure of bioluminescence distribution. Continental Shelf Research, 24, 413-429.

15. Orzech, J. K., \& Nealson, K. H. (1984). Bioluminescence of marine snow, its effect on the optical properties on the sea. International Society for Optics and Photonics, 489, 100-106.

16. Zarubin, M., Belkin, S., Ionescu, M., \& Genin, A. (2012). Bacterial bioluminescence as a lure for marine zooplankton and fish. PNAS, 109, 853-857.

17. Andrews, C. C., Karl, D. M., Small, L. F., \& Fowler, S. W. (1984). Metabolic activity and bioluminescence of oceanic faecal pellets and sediment trap particles. Nature, 307, 539-541.

18. Warrant, E. J., \& Locket, N. A. (2004). Vision in the deep sea. Biological Reviews of the Cambridge Philosophical Society, 79, 671-712.

19. Tanet, L., Martini, S., Casalot, L., \& Tamburini, C. (2020). Reviews and syntheses: Bacterial bioluminescence -ecology and impact in the biological carbon pump. Biogeosciences Discuss, . https://doi.org/10.5194/bg-2020-64.

20. Martini, S., \& Haddock, S. H. D. (2017). Quantification of bioluminescence from the surface to the deep sea demonstrates its predominance as an ecological trait. Science and Reports, 7, 45750.

21. Martini, S., Kuhnz, L., Mallefet, J., \& Haddock, S. H. D. (2019). Distribution and quantifcation of bioluminescence as an ecological trait in the deep sea benthos. Science and Reports, 9, 14654.

22. Ellis, E. A., \& Oakley, T. H. (2016). High rates of species accumulation in animals with bioluminescent courtship displays. Current Biology, 26, 1916-1921.

23. Shimomura, O., \& Yampolsky, I. (2019). Bioluminescence chemical principles and methods. World Scientific.

24. Pant, A., Bag, S., Saha, B., Verma, J., Kumar, P., Banerjee, S., Kumar, B., Kumar, Y., Desigamani, A., Maiti, S., Maiti, T. K., Banerjee, S. K., Bhadra, R. K., Koley, H., Dutta, S., Nair, G. B., Ramamurthy, T., \& Das, B. (2020). Molecular insights into the genome dynamics and interactions between core and acquired genomes of Vibrio cholerae. PNAS, 117, 23762-23773.

25. Boto-Ordonez, M., Urpi-Sarda, M., Queipo-Ortuno, M. I., Tulipani, S., Tinahones, F. J., \& Andres-Lacuevea, C. (2014). High levels of Bifidobacteria are associated with increased levels of anthocyanin microbial metabolites: A randomized clinical trial. Food \& Function, 5, 1932-1938.

26. Ziebuhr, W., Ohlsen, K., Karch, H., Korhonen, T., \& Hacker, J. (1999). Evolution of bacterial pathogenesis. Cellular and Molecular Life Sciences, 56, 719-728.

27. Gennari, M., Ghidini, V., Caburlotto, G., \& Lleo, M. M. (2012). Virulence genes and pathogenicity islands in environmental Vibrio strains nonpathogenic to humans. FEMS Microbiology Ecology, 82, 563-573.

28. Hakvåg, S., Fjærvik, E., Klinkenberg, G., Borgos, S. E. F., Josefsen, K. D., Ellingsen, T. E., \& Zotchev, S. B. (2009). Violaceinproducing Collimonas sp. from the sea surface microlayer of costal waters in Trøndelag, Norway. Marine Drugs, 7, 576-588.

29. Sawabe, T., Ogura, Y., Matsumura, Y., Feng, G., Amin, A. R., Mino, S., Nakagawa, S., Sawabe, T., Kumar, R., Fukui, Y., Satomi, M., Matsushima, R., Thompson, F. L., Gomez-Gil, B., Christen, R., Maruyama, F., Kurokawa, K., \& Hayashi, T. (2013). Updating the Vibrio clades defined by multilocus sequence phylogeny: Proposal of eight new clades, and the description of Vibrio tritonius sp. nov. Frontiers in Microbiology, 4, 414.

30. Dunlap, P.V., Urbanczyk, H. (2013). Prokaryotes. In E. Rosenberg, E. F. DeLong, F. Thompson, S. Lory, E. Stackebrandt (Eds.) Berlin: Springer, 4th edn, pp. 495-528.

31. Sajnaga, E., \& Kazimierczak, W. (2020). Evolution and taxonomy of nematode-associated entomopathogenic bacteria of the genera Xenorhabdus and Photorhabdus: An overview. Symbiosis, 80, 1-13.

32. Fang, Y., Wang, Y., Liu, Z., Dai, H., Cai, H., Li, Z., Du, Z., Wang, X., Jing, H., Wei, Q., Kan, B., \& Wanga, D. (2019). Multilocus sequence analysis, a rapid and accurate tool for taxonomic classification, evolutionary relationship determination, and population biology studies of the genus Shewanella. Applied and Environment Microbiology, 85, e03126-e3218.

33. Ramesh, C. H. (2016). Studies on marine bioluminescent bacteria from Andaman Islands. Pondicherry University.

34. O'Grady, E. A., \& Wimpee, C. F. (2008). Mutations in the lux operon of natural dark mutants in the genus Vibrio. Applied and Environment Microbiology, 74, 61-66.

35. Hedreyda, C. T., \& Orata, F. D. (2011). Amplification and sequence analysis of the luxA gene in the non-luminescent type strain Vibrio campbellii NBRC 15631. Philippine Science Letters, 4, 114-121.

36. Wollenberg, M. S., Preheim, S. P., Polz, M. F., \& Ruby, E. G. (2012). Polyphyly of non-bioluminescent Vibrio fischeri sharing a lux-locus deletion. Environmental Microbiology, 14, 655-668.

37. Rapa, R. A., \& Labbate, M. (2013). The function of integronassociated gene cassettes in Vibrio species: The tip of the iceberg. Frontiers in Microbiology, 4, 385.

38. Kirkup, B. C., Chang, L., Chang, S., Gevers, D., \& Polz, M. F. (2010). Vibrio chromosomes share common history. BMC Microbiology, 10, 137.

39. Gray, K. M., \& Garey, J. R. (2001). The evolution of bacterial LuxI and LuxR quorum sensing regulators. Microbiology, 147 , 2379-2387.

40. Kasai, S., Okada, K., Hoshino, A., Iida, T., \& Honda, T. (2007). Lateral transfer of the lux gene cluster. Journal of Biochemistry, 141, 231-237.

41. Urbanczyk, H., Furukawa, T., Yamamoto, Y., \& Dunlap, P. V. (2012). Natural replacement of vertically inherited lux-rib genes of Photobacterium aquimaris by horizontally acquired homologues. Environmental Microbiology Reports, 4, 412-416.

42. Ast, J. C., Urbanczyk, H., \& Dunlap, P. V. (2007). Natural merodiploidy of the lux-rib Operon of Photobacterium leiognathi from Coastal Waters of Honshu, Japan. Journal of Bacteriology, $189,6148-6158$.

43. Burtseva, O., Kublanovskaya, A., Baulina, O., Fedorenko, T., Lobakova, E., \& Chekanov, K. (2020). The strains of bioluminescent bacteria isolated from the White Sea finfishes: genera Photobacterium, Aliivibrio, Vibrio, Shewanella, and first luminous Kosakonia. Journal of Photochemistry and Photobiology B: Biology, 208, 111895.

44. Vishwakarma, A., Mathur, K., \& Suneetha, V. (2014). Screening and tentative identification of bioluminescence producing bacteria in fish. International Journal of Fisheries and Aquatic Studies, 1, 225-231.

45. Ramesh, C. H., \& Mohanraju, R. (2017). Construction of hypothetical lux operon of ancestral luminous bacteria. Journal of Terrestrial and Marine Research, 1, 71-76.

46. Schmitt, S., Angermeier, H., Schiller, R., Lindquist, N., \& Hentschel, U. (2008). Molecular microbial diversity survey of sponge reproductive stages and mechanistic insights into vertical transmission of microbial symbionts. Applied and Environment Microbiology, 74, 7694-7708.

47. Hazen, T. H., Pan, L., Gu, J. D., \& Sobecky, P. A. (2010). The contribution of mobile genetic elements to the evolution and ecology of Vibrios. FEMS Microbiology Ecology, 74, 485-499.

48. Loening, A. M., Fenn, T. D., Wu, A. M., \& Gambhir, S. S. (2006). Consensus guided mutagenesis of Renilla luciferase yields enhanced stability and light output. Protein Engineering, Design \& Selection, 19, 391-400. 
49. Delroisse, J., Ullrich-Luter, E., Blaue, S., Ortega-Martinez, O., Eeckhaut, I., Flammang, P., \& Mallefet, J. (2017). A puzzling homology: a brittle star using a putative cnidarian-type luciferase for bioluminescence. Open Biology, 7, 160300.

50. Eisner, T., Goetz, M. A., Hill, D. E., Smedley, S. R., \& Meinwald, J. (1997). Firefly 'femmes fatales' acquire defensive steroids (lucibufagins) from their firefly prey. Proceedings of the National academy of Sciences of the United States of America, 94, 9723-9728.

51. Smedley, S. R., Risteen, R. G., Tonyai, K. K., Pitino, J. C., Hu, Y., Ahmed, Z. B., Christofel, B. T., Gaber, M., Howells, N. R., Mosey, C. F., Rahim, F. U., \& Deyrup, S. T. (2021). Bufadienolides (lucibufagins) from an ecologically aberrant firefly (Ellychnia corrusca). Chemoecology, 27, 141-153.

52. Daly, J. W., Kaneko, T., Wilham, J., Garraffo, H. M., Spande, T. F., Espinosa, A., \& Donnelly, M. A. (2002). Bioactive alkaloids of frog skin: Combinatorial bioprospecting reveals that pumiliotoxins have an arthropod source. Proceedings of the National Academy of Sciences of the United States of America, 99, 13996-14001.

53. Santos, J. C., Coloma, L. A., \& Cannatella, D. C. (2003). Multiple, recurring origins of aposematism and diet specialization in poison frogs. Proceedings of the National Academy of Sciences of the United States of America, 100, 12792-12797.

54. Petschenka, G., \& Agrawal, A. A. (2015). Milkweed butterfly resistance to plant toxins is linked to sequestration, not coping with a toxic diet. Proceedings of the Royal Society B: Biological Sciences, 282, 20151865.

55. Widder, E. A. (2010). Bioluminescence in the ocean: Origins of biological, chemical, and ecological diversity. Science, 328, 704-708.

56. Markova, S. V., \& Vysotski, E. S. (2015). Coelenterazinedependent luciferases. Biochemistry, 80, 714-732.

57. Tsuji, F. I., Haneda, Y., Lynch, R. V., \& Sugiyama, N. (1971). Luminescence cross-reactions of Porichthys luciferin and theories on the origin of luciferin in some shallow-water fishes. Comparative Biochemistry and Physiology, A: Comparative Physiology, 40, 163-179.

58. Thompson, E. M., Toya, Y., Nafpaktitis, B. G., Goto, T., \& Tsuji, F. I. (1988). Induction of bioluminescence capability in the marine fish, Porichthys notatus, by Vargula (Crustacean) [14C] luciferin and unlabelled analogues. Journal of Experimental Biology, 137, 39-51.

59. Thompson, E. M., Nafpaktitis, B. G., \& Tsuji, F. I. (1987). Induction of bioluminescence in the marine fish Porichthys by Vargula (crustacean) luciferin. Evidence for de novo synthesis or recycling of luciferin. Photochemistry and Photobiology, 45, 529-533.

60. Mallefet, J., \& Shimomura, O. (1995). Presence of coelenterazine in mesopelagic fishes from the Strait of Messina. Marine Biology, 124, 381-385.

61. Thomson, C. M., Herring, P. J., \& Campbell, A. K. (1997). The widespread occurrence and tissue distribution of the imidazolopyrazine luciferins. Journal of Bioluminescence and Chemiluminescence, 12, 87-91.

62. Shimomura, O., Inoue, S., Johnson, F. H., \& Haneda, Y. (1980). Widespread occurrence of coelenterazine in marine bioluminescence. Comparative Biochemistry and Physiology, 65, 435-437.

63. Campbell, A. K., \& Herring, P. J. (1990). Imidazolopyrazine bioluminescence in copepods and other marine organisms. Marine Biology, 104, 219-225.

64. Rodriguez, J. D., Haq, S., Bachvaroff, T., Nowak, K. F., Nowak, S. J., Morgan, D., Cherny, V. V., Sapp, M. M., Bernstein, S., Bolt, A., \& DeCoursey, T. E. (2017). Identification of a vacuolar proton channel that triggers the bioluminescent flash in dinoflagellates. PLoS ONE, 12, e0171594.
65. Liu, L., \& Hastings, J. W. (2007). Two different domains of the luciferase gene in the heterotrophic dinoflagellate Noctiluca scintillans occur as two separate genes in photosynthetic species. Proceedings of the National Academy of Sciences of the United States of America, 104, 696.

66. Dunlap, J. C., Hastings, J. W., \& Shimomura, O. (1981). Dinoflagellate luciferin is structurally related to chlorophyll. FEBS Letters, 135, 273-276.

67. Topalov, G., \& Kishi, Y. (2001). Chlorophyll catabolism leading to the skeleton of dinoflagellate and krill luciferins: Hypothesis and model studies. Angewandte Chemie International Edition, 40, 3892-3894.

68. Nakamura, H., Kishi, Y., Shimomura, O., Morse, D., \& Hastings, J. W. (1989). Structure of dinoflagellate luciferin and its enzymic and nonenzymic air-oxidation products. Journal of the American Chemical Society, 111, 7607-7611.

69. Shimomura, O. (1995). The roles of the two highly unstable components $\mathrm{F}$ and $\mathrm{P}$ involved in the bioluminescence of euphausiid shrimps. Journal of Bioluminescence and Chemiluminescence, 10, 91-101.

70. Shimomura, O. (1980). Chlorophyll-derived bile pigment in bioluminescent euphausiids. FEBS Letters, 116, 203-206.

71. Dunlap, J. C., Hastings, J. W., \& Shimomura, O. (1980). Crossreactivity between the light-emitting systems of distantly related organisms: Novel type of light-emitting compound. PNAS, 77, 1394-1397.

72. Marie, R., \& Mallefet, J. (2013). First study of the chemistry of the luminous system in a deep-sea shark, Etmopterus spinax Linnaeus, 1758 (Chondrichthyes: Etmopteridae). Journal of Experimental Marine Biology and Ecology, 448, 214-219.

73. Shimomura, O. (1987). Presence of coelenterazine in nonbioluminescent marine organisms. Comparative Biochemistry and Physiology, 86B, 361-363.

74. Duchatelet, L., Hermans, C., Duhamel, G., Cherel, Y., Guinet, C., Mallefet, J. (2019). In Proceedings of the Second Symposium on Kerguelen Plateau: marine ecosystem and fisheries, Australian Antartic Division, Kingston, Tasmania, Australia, pp. 31-41.

75. Frank, T. M., Widder, E. A., Latz, M. I., \& Case, J. F. (1984). Dietary maintenance of bioluminescence in a deep-sea mysid. Journal of Experimental Biology, 109, 385-389.

76. Mallefet, J., Duchatelet, L., \& Coubris, C. (2020). Bioluminescence induction in the ophiuroid Amphiura filiformis (Echinodermata). The Journal of Experimental Biology, 223(4), jeb.218719.

77. Davis, M. P., Sparks, J. S., \& Smith, W. L. (2016). Repeated and widespread evolution of bioluminescence in marine fishes. PLoS ONE, 11, 0155154.

78. Paitio, J., Oba, Y., \& Meyer-Rochow, V. B. (2016). Bioluminescent fishes and their eyes. In T. Jagannathan (Ed.), Luminescence-an outlook on the phenomena and their applications (pp. 297-332). London: IntechOpen.

79. Suntsov, A. V., Widder, E. A., \& Suton, T. T. (2008). Bioluminescence. In R. N. Finn \& B. G. Kapoor (Eds.), Fish Larval Physiology (pp. 51-88). Enield: Science Publishers.

80. Mizuno, G., Yano, D., Paitio, J., Endo, H., \& Oba, Y. (2021). Lantern shark Etmopterus use coelenterazine as substrate for their luciferin-luciferase bioluminescence system. Biochemical and Biophysical Research Communications, 577, 139-145.

81. Thomson, C. M., Herring, P. J., \& Campbell, A. K. (1995). Coelenterazine distribution and luciferase characteristics in oceanic decapod crustaceans. Marine Biology, 124, 197-207.

82. Thomson, C. M., Herring, P. J., \& Campbell, A. K. (1995). Evidence for de novo biosynthesis of coelenterazine in the bioluminescent midwater shrimp, Systellaspis debilis. Journal of the Marine Biological Association of the United Kingdom, 75, $165-171$. 
83. Oba, Y., Ichi-Kato, S., Ojika, M., \& Inouye, S. (2009). Biosynthesis of coelenterazine in the deep-sea copepod, Metridia pacifica. Biochemical and Biophysical Research Communications, 309, 684-688.

84. Oba, Y., Schultz, D.T. (2014). Bioluminescence: Fundamentals and applications in biotechnology-volume 1. In: G. Thouand and R. Marks (Eds.) Berlin, Heidelberg: Springer, pp. 3-36.

85. Lau, E. S., \& Oakley, T. H. (2021). Multi-level convergence of complex traits and the evolution of bioluminescence. Biological Reviews, 96, 673-691.

86. Duchatelet, L., Flammang, P., Mahillon, J., \& Mallefet, J. (2019). Etmopterus spinax, the velvet belly lanternshark, does not use bacterial luminescence. Acta Histochemica, 121, 516-521.

87. Gonzalez, V. M. (2007). Synthesis, luminescence, and applications of coelenterazine and its analogs. https://chemistry.illinois. edu/system/files/inline-files/03GonzalezFINALAbstract.pdf. Accessed May 23, 2021.

88. Mosrin, M., Bresser, T., \& Knochel, P. (2009). Regio- and chemoselective multiple functionalization of chloropyrazine derivatives. Application to the synthesis of coelenterazine. Organic Letters, 11, 3406-3409.

89. Nakamura, H., Wu, C., Inouye, S., \& Murai, A. (2001). Design, synthesis, and evaluation of the transition-state inhibitors of coelenterazine bioluminescence: Probing the chiral environment of active site. Journal of the American Chemical Society, 123, 1523-1524.

90. Shakhmin, A., Hall, M. P., Walker, J. R., Machleidt, T., Binkowski, B. F., Wood, K. V., \& Kirkland, T. A. (2016). Three efficient methods for preparation of coelenterazine analogues. Chemistry-A European Journal, 22, 10369-10375.

91. Adamczyk, M., Johnson, D. D., Mattingly, P. G., Pan, Y., \& Reddy, R. E. (2001). Synthesis of coelenterazine. Organic Preparations and Procedures International, 33, 477-485.

92. Nishihara, R., Citterio, D., \& Suzuki, K. (2016). Methods in molecular biology (pp. 19-31). Berlin: Humana Press Inc.

93. Shrestha, T. B., Troyer, D. L., \& Bossmann, S. H. (2014). Strategies for large-scale synthesis of coelenterazine for in vivo applications. Synthesis, 46, 646-652.

94. Coutant, E. P., Goyard, S., Hervin, V., Gagnot, G., Baatallah, R., Jacob, Y., Rose, T., \& Janin, Y. L. (2019). Gram-scale synthesis of luciferins derived from coelenterazine and original insights into their bioluminescence properties. Organic \& Biomolecular Chemistry, 17, 3709.

95. Tessler, M., Gaffney, J. P., Crawford, J. M., Trautman, E., Gujarati, N. A., Alatalo, P., Pieribone, V. A., \& Gruber, D. F. (2018). Luciferin production and luciferase transcription in the bioluminescent copepod Metridia lucens. PeerJ, 2018, e5506.

96. Francis, W. R., Shaner, N. C., Christianson, L. M., Powers, M. L., \& Haddock, S. H. D. (2015). Occurrence of isopenicillin-nsynthase homologs in bioluminescent ctenophores and implications for coelenterazine biosynthesis. PLOS ONE, 10, e0128742.

97. Warner, J. A., \& Case, J. F. (1980). The zoogeography and dietary induction of bioluminescence in the midshipman fish, Porichthys notatus. Biological Bulletin, 159, 231-246.

98. Barnes, A. T., Case, J. F., \& Tsuji, F. I. (1973). Induction of bioluminescence in a luciferin deficient form of the marine teleost Porichthys, in response to exogenous luciferin. Comparative Biochemistry and Physiology-Part A Comparative Physiology, 46, 709-723.

99. Mensinger, A. F., \& Case, J. F. (1991). Bioluminescence maintenance in juvenile Porichthys notatus. Biological Bulletin, 181, 181-188.

100. Haneda, Y., Tsuji, F. I., \& Sugiyama, N. (1969). Luminescent systems in Apogonid fishes from the Philippines. Sci. Sci., 165, 188-190.
101. Haneda, Y., Johnson, F.H., Shimomura, O. (1966). Bioluminescence in Progres. In F.H. Johnson and Y. Haneda (Eds.) Princeton: Princeton University Press, pp. 533-546.

102. Oba, Y., Kato, S., Ojika, M., \& Inouye, S. (2002). Biosynthesis of luciferin in the sea firefly, Cypridina hilgendorfii: L-tryptophan is a component in Cypridina luciferin. Tetrahedron Letters, 43, 23892392.

103. Kato, S., Oba, Y., Ojika, M., \& Inouye, S. (2004). Identification of the biosynthetic units of Cypridina luciferin in Cypridina (Vargula) hilgendorfii by LC/ESI-TOF-MS. Tetrahedron Letters, 60, 11427-11434.

104. Tessler, M., Gaffney, J. P., Oliveira, A. G., Guarnaccia, A., Dobi, K. C., Gujarati, N. A., Galbraith, M., Mirza, J. D., Sparks, J. S., Pieribone, V. A., Wood, R. J., \& Gruber, D. F. (2020). A putative chordate luciferase from a cosmopolitan tunicate indicates convergent bioluminescence evolution across phyla. Science and Reports, 10, 17724.

105. Maeda, T., Takahashi, S., Yoshida, T., Shimamura, S., Takaki, Y., Nagai, Y., Toyoda, A., Suzuki, Y., Arimoto, A., Ishii, H., Satoh, N., Nishiyama, T., Hasebe, M., Maruyama, T., Minagawa, J., Obokata, J., \& Shigenobu, S. (2021). Chloroplast acquisition without the gene transfer in kleptoplastic sea slugs, Plakobranchus ocellatus. eLife, 10, e60176.

106. Goodheart, J. A., \& Bely, A. E. (2017). Sequestration of nematocysts by divergent cnidarian predators: Mechanism, function, and evolution. Invertebrate Biology, 136, 75-91.

107. Lewis, S. M., Faust, L., \& De Cock, R. (2012). The dark side of the light show: predators of fireflies in the great smoky mountains. Psyche (London), 2012, 634027.

108. Soliev, A.B., Enomoto, K. (2013). Marine biomaterials: Characterization, Isolation and applications. In S. Kim (Ed.) London: CRC Press, pp. 149-171.

109. Luesch, H., Harrigan, G., Goetz, G., \& Horgen, F. (2012). The cyanobacterial origin of potent anticancer agents originally isolated from sea hares. Current Medicinal Chemistry, 9, 1791-1806.

110. Okazaki, T., Kitahara, T., \& Okami, Y. (1975). Studies on marine microorganisms. IV a new antibiotic SS-228 Y produced by chainia isolated from shallow sea mud. The Journal of Antibiotics Tokyo, 28, 176-184.

111. Franks, A., Haywood, P., Holmström, C., Egan, S., Kjelleberg, S., \& Kumar, N. (2005). Isolation and structure elucidation of a novel yellow pigment from the marine bacterium Pseudoalteromonas tunicata. Molecules, 10, 1286-1291.

112. Blackman, A. J., \& Li, C. P. (1994). New tambjamine alkaloids from the marine bryozoan Bugula dentata. Australian Journal of Chemistry, 47, 1625-1629.

113. Pinkerton, D. M., Banwell, M. G., Garson, M. J., Kumar, N., De Moraes, M. O., Cavalcanti, B. C., Barros, F. W. A., \& Pessoa, C. (2010). Antimicrobial and cytotoxic activities of synthetically derived tambjamines C and E-J, BE-18591, and a related alkaloid from the marine bacterium Pseudoalteromonas tunicata. Chemistry \& Biodiversity, 7, 1311-1324.

114. Ramesh, C. H., Bhushanrao, T., Mohanraju, R., Thakur, N., \& Dufossé, L. (2021). Marine natural products from tunicates and their associated microbes. Marine Drugs, 19, 308.

115. Tanet, L., Tamburini, C., Baumas, C., Garel, M., Simon, G., \& Casalot, L. (2019). Bacterial bioluminescence: Light emission in Photobacterium phosphoreum is not under quorum-sensing control. Frontiers in Microbiology, 10, 365.

116. Nyholm, S. V., \& McFall-Ngai, M. J. (2004). The winnowing: Establishing the squid-vibrio symbiosis. Nature Reviews Microbiology, 2, 632-642.

117. Mandel, M. J., \& Dunn, A. K. (1982). Impact and influence of the natural Vibrio-squid symbiosis in understanding 
bacterial-Animal interactions. Frontiers in Microbiology, 2016, 7.

118. Verma, S. C., \& Miyashiro, T. (2013). Quorum sensing in the squid-vibrio symbiosis. International Journal of Molecular Sciences, 14, 16386-16401.

119. Ohbayashi, T., Mergaert, P., Kikuchi, Y. (2020). Advances in insect physiology Volume 58. In K. M. Oliver, J. A. Russell (Eds.) Academic Press, London, pp. 27-62.

120. Haygood, M. G. (1993). Light a organ symbioses in fishes. Critical Reviews in Microbiology, 19, 191-216.

121. Hendry, T. A., de Wet, J. R., \& Dunlap, P. V. (2014). Genomic signatures of obligate host dependence in the luminous bacterial symbiont of a vertebrate. Environmental Microbiology, 16, 2611-2622.

122. Gyllborg, M. C., Sahl, J. W., Cronin, D. C., Rasko, D. A., \& Mandel, M. J. (2012). Draft genome sequence of Vibrio fischeri SR5, a strain isolated from the light organ of the Mediterranean Squid Sepiola robusta. Journal of Bacteriology, 194, 1639.

123. Mandel, M. J., Wollenberg, M. S., Stabb, E. V., Visick, K. L., \& Ruby, E. G. (2009). A single regulatory gene is sufficient to alter bacterial host range. Nature, 458, 215-218.

124. Zink, K. E., Ludvik, D. A., Lazzara, P. R., Moore, T. W., Mandel, M. J., \& Sanchez, L. M. (2021). A small molecule coordinates symbiotic behaviors in a host organ. MBio, 12, e03637-e3720.

125. Haygood, M. G., Tebo, B. M., \& Nealson, K. H. (1984). Luminous bacteria of a monocentrid fish (Monocentris japonicus) and two anomalopid fishes (Photoblepharon palpebratus and Kryptophanaron alfredi): Population sizes and growth within the light organs, and rates of release into the seaw. Marine Biology, 78, 249-254.

126. Ramesh, C. H., \& Mohanraju, R. (2019). A review on ecology, pathogenicity, genetics and applications of bioluminescent bacteria. Journal of Terrestrial and Marine Research, 3, 1-32.

127. Dunlap, P. V., \& Nakamura, M. (2011). Functional morphology of the luminescence system of Siphamia versicolor (Perciformes: Apogonidae), a bacterially luminous coral reef fish. Journal of Morphology, 272, 897-909.

128. Hendry, T. A., \& Dunlap, P. V. (2014). Phylogenetic divergence between the obligate luminous symbionts of flashlight fishes demonstrates specificity of bacteria to host genera. Environmental Microbiology Reports, 6, 331-338.

129. Nealson, K. H. (1978). Isolation, identification and manipulation of luminous bacteria. Methods in Enzymology, 57, 153-166.

130. Hastings, J. W., \& Nealson, K. H. (1977). Bioluminescence. Annual Review of Microbiology, 31, 549-595.

131. Ast, J. C., Cleenwerck, I., Engelbeen, K., Urbanczyk, H., Thompson, F. L., Vos, P. D., \& Dunlap, P. V. (2007). Photobacterium kishitanii sp. nov., a luminous marine bacterium symbiotic with deep-sea fishes. International Journal of Systematic and Evolutionary Microbiology, 57, 2073-2078.

132. Hendry, T. A., Freed, L. L., Fader, D., Fenolio, D., Sutton, T. T., \& Lopez, J. V. (2018). Ongoing transposon-mediated genome reduction in the luminous bacterial symbionts of deep-sea ceratioid anglerfishes. MBio, 9, e01033.

133. Hendry, T. A., De Wet, J. R., Dougan, K. E., \& Dunlap, P. V. (2016). Genome evolution in the obligate but environmentally active luminous symbionts of flashlight fish. Genome Biology and Evolution, 8, 2203-2213.

134. Baker, L. J., Freed, L. L., Easson, C. G., Lopez, J. V., Fenolio, D., Sutton, T. T., Nyholm, S. V., \& Hendry, T. A. (2020). Diverse deep-sea anglerfishes share a genetically reduced luminous symbiont that is acquired from the environment. eLife, 8, e47606.

135. Freed, L. L., Easson, C., Baker, L. J., Fenolio, D., Sutton, T. T., Khan, Y., Blackwelder, P., Hendry, T. A., \& Lopez, J. V. (2019). Characterization of the microbiome and bioluminescent symbionts across life stages of Ceratioid Anglerfishes of the Gulf of Mexico. FEMS Microbiology Ecology. https://doi.org/10.1093/ femsec/fiz146

136. Miller, S. D., Haddock, S. H. D., Elvidge, C. D., \& Lee, T. F. (2005). Detection of a bioluminescent milky sea from space. Proceedings of the National Academy of Sciences of the United States of America, 102, 14181-14184.

137. Miller, S. D., Haddock, S. H. D., Straka, W. C., Seaman, C. J., Combs, C. L., Wang, M., Shi, W., \& Nam, S. (2021). Honing in on bioluminescent milky seas from space. Science and Reports, $11,15443$.

138. Tamburini, C., Canals, M., de Madron, X. D., Houpert, L., et al. (2013). Deep-sea bioluminescence blooms after dense water formation at the ocean surface. PLoS ONE, 8, e67523.

139. Copilas-Ciocianu, D., \& Pop, F. M. (2020). An account of bacterial-induced luminescence in the Ponto-Caspian amphipod Pontogammarus maeoticus (Sowinskyi, 1894), with an overview of amphipod bioluminescence. North-Western Journal of Zoology, $16,238-240$.

140. Harvey, E. N. (1957). A history of luminescence from the earliest times until 1900. American Philosophical Society.

141. Gerrard, J. G., McNevin, S., Alfredson, D., Forgan-Smith, R., \& Fraser, N. (2003). Photorhabdus species: Bioluminescent bacteria as emerging human pathogens? Emerging Infectious Diseases, 9, 251-254.

142. Lang, A. E., Kühn, S., \& Mannherz, H. G. (2016). Current topics in microbiology and immunology (pp. 53-67). Berlin: Springer.

143. Gerdes, E., Upadhyay, D., Mandjiny, S., Bullard-Dillard, R., Storms, M., Menefee, M., \& Holmes, L. D. (2015). Photorhabdus luminescens: Virulent properties and agricultural applications. American Journal of Agricultural Economics, 3, 171-177.

144. Patterson, W., Upadhyay, D., Mandjiny, S., Bullard-Dillard, R., Storms, M., Menefee, M., \& Holmes, L. D. (2015). Attractant role of bacterial bioluminescence of Photorhabdus luminescens on a Galleria mellonella model. American Journal of Life Sciences, 3, 290-294.

145. Rees, J. F., Thompson, E. M., Baguet, F., \& Tsuji, F. I. (1990). Detection of coelenterazine and related luciferase activity in the tissues of the luminous fish, Vinciguerria attenuata. Comparative Biochemistry and Physiology-Part A, 96A, 425-430.

146. Urbanczyk, H., Ogura, Y., Hendry, T. A., Gould, A. L., Kiwaki, N., Atkinson, J. T., Hayashi, T., \& Dunlap, P. V. (2011). Genome sequence of Photobacterium mandapamensis strain svers.1.1, the bioluminescent symbiont of the cardinal fish Siphamia versicolor. Journal of Bacteriology, 193, 3144-3145. 


\section{Authors and Affiliations}

\section{Chatragadda Ramesh ${ }^{1}$ [ $\cdot$ Manabu Bessho-Uehara ${ }^{2,3}$}

$\triangle$ Chatragadda Ramesh chramesh@nio.org

2 Institute for Advanced Research, Nagoya University Furo-Cho, Chikusa-ku, Nagoya, Aichi 464-8601, Japan

1 Biological Oceanography Division (BOD), CSIR-National Institute of Oceanography (CSIR-NIO), Dona Paula 403004,

3 Graduate School of Science, Nagoya University Furo-Cho, Chikusa-ku, Nagoya, Aichi 464-8601, Japan 